\title{
Management Skill Development of Academic \\ Institutional Heads in Bangladesh: A Conceptual Study on Henri Fayol's Management Principles
}

Idris Ali,

Postgraduate Research Fellow, Department of Social Foundation \& Educational Leadership, Kulliyyah of Education, International Islamic University Malaysia

Fatima Kanis Nayan

Ph.D Candidate, Greenwich Business School, University of Greenwich, UK

Md Atiqur Rahman Sarker*

Postgraduate Research Fellow, Department of Business Administration, International Islamic University Malaysia \& Assistant Professor,

East West University, Bangladesh

Md Tahmidur Rahman Kadery

Student (Bachelor of Business Administration), Department of Marketing, Bangladesh University of Professionals (BUP), Dhaka, Bangladesh

Yayan Firmansah

Faculty Member, Department of Management,

University of Darussalam Gontor, Indonesia.

Received: Mar. 18, 2021 Accepted: Jun. 1, 2021 Online published: Jun. 16, 2021

doi:10.5296/ijhrs.v11i3.18428 URL: https://doi.org/10.5296/ijhrs.v11i3.18428 


\section{Il Macrothink}

International Journal of Human Resource Studies

ISSN 2162-3058

2021, Vol. 11, No. 3

\section{Abstract}

This study investigates the managerial problems faced by the institutional heads in the area of educational management in Bangladesh. The aim of this article is to recognize the key influences, challenges and barriers of the organizational heads in the education management sectors and to pursue the adequate solution of those complications, which are the strong barriers to achieving the organizational objectives in the field of educational management. For this research, qualitative descriptive methodology was employed to collect secondary data from different authentic sources. In Bangladesh, organizational leaders in education sector face numerous challenges and difficulties in carrying out their managerial activities in the field of educational management. In terms of administrative abilities, they have immense gaps and deficiencies in conducting their respective actions and obligations in the educational institution, such as managing the institutes with supervision, control, assessment, motivation and effective utilization of resources. This study is critically reviewing the Henri Fayol's 14 principles for application into educational management. This study also recommends Henri Fayol's principles for developing management skills of academic institutional heads.

Keywords: academic institutional heads, Bangladesh, Henri Fayol's 14 Principles, management skill development

\section{Introduction}

Management skills are essential in operational efficiency. It is needed for every sector. Excellence in education also requires effective management system. Higher education institutions runs under the patronage of institutional head, who manages both teaching and non-teaching employees as well as students for education purpose. This actually refers educational management, in which the authority absorbs human and material resources to monitor, prepare, formulate strategies and implement the framework of the education system (Shimin, 2018). However, the concept of education management is universal, including goal setting, plan formulation, personal supervision and encouragement, action coordination and control, goal achievement, and evaluation of joint efforts to achieve these goals (Taylor et al., 2020). The overall goal of education management is to establish and maintain an environment within educational institutions to encourage, promote, and effectively carry out the excellent and efficient teaching as well as learning. Practicing management literacy into the education system reflects on academic results of students and their moral behaviors which are directly related to growth and the internal development of the human system for moving forward (Al-Hammadi, 2019). This paper fundamentally explores the key variables of education management in Bangladesh and seeks sustainable solutions. However, educational management in Bangladesh has many shortcomings related to managerial skills and gaps in practicing educational management by the institutional heads. Rozario (2018) stated that most of the organizational heads do not follow any effective models and principles to manage academic activities, so the organizational administrators cannot effectively manage administrative affairs. In the absence of the concepts of educational management, there are enormous disparities in the knowledge and management skills of organizational leaders in the field of educational management in Bangladesh. 
It is argued that managerial skills and management principles are the driving force of the entire educational management process and improvement in the educational institution (Cooper \& Hughes, 2017). Contemporary management methods mainly focus on the managerial skills development of educational heads including planning, organizing, controlling, evaluation, motivating, supervising, confidence building and teamwork, which are more important for conducting educational organization effectively to achieve the academic institutional goals and objectives. Effective management practices are important prerequisites for ensuring the development of managerial skills of academic heads which has positive impact on providing better quality learning and teaching including the achievement of organizational goals (Masud et al., 2021). This study is referring the practice of 14 management principles of Henri Fayol by the academic heads to discover the challenges that they face and take effective and efficient management actions time to time. The study also provides the details about the current educational management practices in Bangladesh and recommends the ways to manage the challenges that academic heads face in operating the educational institutions. This study can draw the attention of policy makers in education sector and the management bodies for further action and improvement. In addition, this research also helps to reveal the problems in the field of education management, so that educational leaders and other stakeholders can solve the problems.

\section{Literature Review}

Bangladesh has different educational institutions (such as primary, secondary and higher secondary schools, colleges and universities) in both private and public sectors. The heads of many academic institutions face tremendous pressure and challenges regularly. Bangladesh's educational management institutions have many shortcomings in management and leadership. Due to the gaps in terms of implementation of educational management principles, they cannot provide quality education. The present educational management systems in Bangladesh does not provide clear roles, concepts and responsibilities, management elements in terms of principles, necessary policies, procedures and systems as well as the strategic processes that are more effective and prerequisites for the educational administrators and organizational heads to achieve the organizational goals. This leads to a lack of comprehensibility, which directs to a lack of understanding of the necessity to implement laws, regulations, and tools to monitor and evaluate results or performance (Yaya et al., 2017). As a result, in the past few decades, institutional heads and policymakers were unable to prepare any action strategies for education management to implement the management principles in the management sectors. Rahman (2020) argued that most of the academic heads do not concern about the organizational vision, mission, or goals and the elements of educational management principles is a new concept to them. At the same time, the organizational heads, administrators and policymakers have not yet realized the major concepts of educational management principles such as division of works, authority and responsibilities, discipline, unity of commends, unity of directions, the subordination of individual interest, as well as the mechanisms, methods, technicality, and quantifiability. As a result, they cannot apply these to their respective fields in educational management.

One of the studies found that organizational leaders began to act as academic institutional 
chiefs and managers, but they do not have better understanding on the education philosophy and managerial skills. The credentials are the only prerequisite; no concern is on performance management (Ruben \& Gigliotti, 2016). They have never been concerned about the roles and responsibilities of the position and are unwilling to learn about the knowledge and information from the viewpoints of increasing the development of managerial skills. Many academic heads do not follow the strategic plans, rules, and regulations that have a negative impact on their daily tasks, such as irregular classes, delayed grades, and late publication of exam results (Fortunato et al., 2017). At the same time, there is a huge gap in terms of knowledge, standard and managerial skills, and communication between the top management. The governing body of the academic institution is free from transforming plans into policies or implementing any policies through necessary activities. As a result, with a few exceptions, educational management concept and principles are still an ambiguous term for most of the educational administrators and staffs (Bank \& Popoola, 2018; Christens et al., 2018). Connolly et al., (2017) claimed that there is no systematic approach to the educational management and organizational structure in Bangladesh (such as policy formulation, policy implementation practices, systematic academic research and administrative processes, and accountability). Consequently, a structured framework for planning, preparing, organizing, management process or performance evaluation of educational management have not been developed, and the academic heads and staffs in the management fields in Bangladesh have a serious lack of understanding of the concepts of management principles and management process and skills (Castillo \& Hallinger, 2017). As a result, they failed to complete its academic programs and activities to achieve the goals of educational management in Bangladesh.

In the era of educational management, there is an increasing demand for educational management in Bangladesh. However, most of the organizational heads are struggling to meet the emerging demand for developing managerial skills (Hallinger, 2017). According to Amin (2018), no formal management structure has been established for educational management such as planning, training, organizing, controlling, performance evaluation system in the educational institutions in Bangladesh. At the same time, most of the academic heads have lack of understanding of the major components of management principles, concepts, and management process, such as providing remuneration, the degree of centralization, scalar chain, order, equity, the stability of tenure personnel, initiatives and spirit de corps. In terms of managerial skills development of academic heads, there are no significant studies on educational management in Bangladesh. Previous research has concentrated on the overall standard of quality education. As a result, the organizational heads failed to complete their academic courses and activities to achieve the goals of educational management in Bangladesh (Bank \& Popoola, 2018). This study decisively scrutinizes the factors of educational management from the perspective of increasing the managerial skills of academic heads and administrators. This study also tries to explore the fundamental factors especially the fourteen principles of educational management developed by Henri Fayol which influence to develop and enhance the managerial skills and efficacy of educational heads and administrators to gain a competitive advantage in the education sector of Bangladesh. At the same time, this study also contributes significantly to explore the major 


\section{Macrothink}

International Journal of Human Resource Studies

ISSN 2162-3058

2021, Vol. 11, No. 3

elements of educational management principles to promote the managerial skills of academic heads and other administrators in educational management fields particularly in Bangladesh.

\section{Critical Review on Henri Fayol's 14 Management Principles for Educational Management in Bangladesh}

Henri Fayol in 1925 developed 14 principles for effective management of the organization. These are also considered to be the basic components of management principles, especially in the field of education. However, these management concepts can be used as a framework for various purpose in management especially for the development of managerial skills of educational heads in the academic institutions. The key components of Henri Fayol's management principles are discussed below and the connection of each principles in educational management is also explained subsequently.

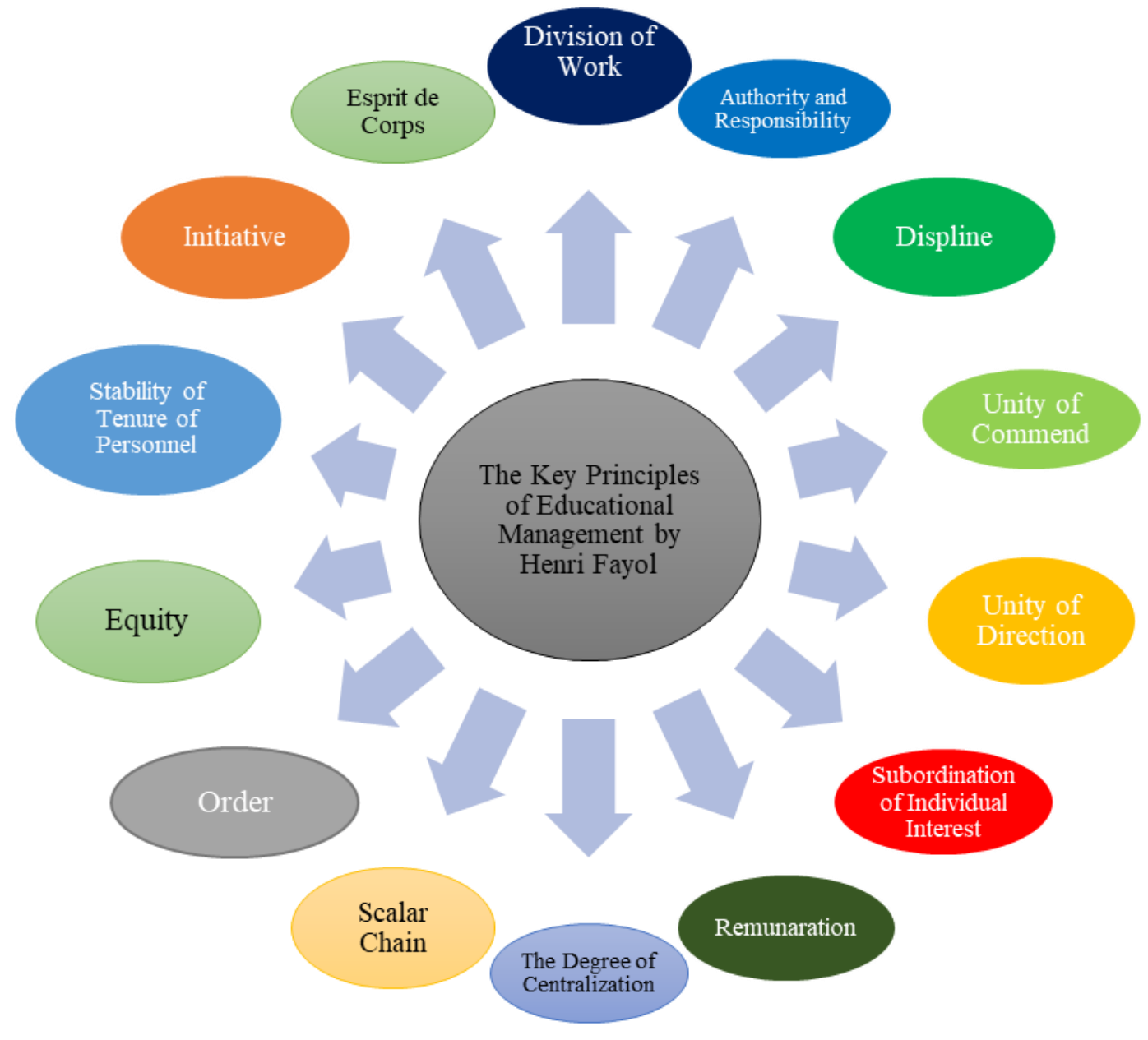

Figure 1. 14 Management Principles of Henri Fayol 1925

\section{Division of Work}

Division of labor refers to various activities that are performed by a different individual or group of people (Serdyukov, 2017). However, the workers are specialized in various fields and they have different skills. In the field of knowledge (from generalist to expert), different 
ability levels can be distinguished. This is the support of personal and professional innovation. Henri Fayol believes that specialization can improve employee quality and managerial skills in the organizations particularly in the educational institutions (Sanyang, 2019). Moreover, the specialization of workers improves their accuracy and speed. The management philosophy of these 14 management principles applies to the technical and management activities of all organizations especially educational institutions (Cletus \& Ibrahim, 2018). There are two basic type of employment exist at school job. One is academic job (teachers) and another is non-academic job (administrator, clerks and office assistants). It has been seen that teacher alone work more and have less time to focus on education and teaching. Therefore, work division in the management is a great issue and one of the most important components of management principles which has a positive impact on the educational organizations. It is recommended that employees at schools are well-equipped with division of work.

\section{Authority and Responsibility}

The authorities have the legal right to issue orders, commands or gives instructions and force subordinates to take specific actions. However, responsibility is the product of authority. It includes the responsibilities of the subordinates, who have been granted the responsibilities of the superior (Khasawneh \& Hammadat, 2015). The authority establishes a clear chain of command from the top to the bottom of the organization. In this way, a unified order is formed: everyone takes orders from the organizational heads, eliminating uncertainty and increasing transparency. In short, authority and responsibility are complementary, they are two sides of the same coin (Bell \& Bodie, 2019). Therefore, jurisdiction and responsibility are two key parts of the smooth running of administrative work within an organization. This is also applicable in managing educational institutions.

\section{Discipline}

Discipline implies prescribed behavior or actions. The discipline of employees at work can be manifested in compliance with company policies, laws, regulations and procedures established by management (Service, 2019). As Jim Rohan correctly said: "Discipline is the bridge between goal and achievement". In the context of good behavior and respectful contact, it is also part of the mission statement and the core principles of the vision. This management theory is very important and is seen as the driving force for the smooth operation of the organization's engine. Moreover, discipline ensures that individuals remain quiet at work and work with team members as a collective entity to accomplish organizational goals (Valente et al., 2019). At the same time, discipline is the lifeline of an organization and without it, employees not only misbehave, but they will do whatever they want (Service, 2019). Discipline, therefore, plays a significant role in the creation and preservation of self-control, respect for others and appropriate conduct in the field of governance, especially in educational institutions.

\section{Unity of Command}

Unified command means that all workers work under a single boss or administrative head and 
have the appropriate power to command all forces used to achieve common goals. If more than one manager assigns responsibilities and related roles to employees, it may cause uncertainty and may lead to conflicts among employees in the organization (Uzuegbu, 2016). By applying this theory, fault liability can be defined more effectively. Furthermore, unity of command is a management concept that creates a hierarchy in which subordinates report or are only responsible for a single superior who is directly above their position (Bacud, 2020). Thus, the unity of command plays a vital role in the rapid and successful deployment of incident response teams in the organization. This principle is also relevant in education management as the institute runs under the supervision of the head. Here, students, teachers and non-teaching staffs should follow the direction of the head of the institute to achieve the common goal, which is excellence in education.

\section{Unity of Direction}

Unity of direction is a management principle, which means that all activities with the same goal must have a mind and a plan. However, all employees perform the same activities that can be linked to the same goal. All activities must be carried out by a group of teams. These activities must be described in the Action Plan (Adam, 2019b). The manager or agency head is ultimately responsible for this plan and monitors the progress of defined and planned activities. The focus area is employee effort and coordination. Moreover, the consistent direction can promote the achievement of organizational goals without difficulty and without repeating activities (Adam, 2019a). Thus, unity of direction in the organization provides the way to utilize the capabilities that help to achieve the institutional goals. It is also suggested for educational management discipline to follow for greater success.

\section{Subordination of Individual Interest}

This principle states that general interest is superior to individual interest. Each individual joins the organization with certain expectations and objective. And everyone works to achieve his objective. The interests of individuals or parties should not override general interests (Kim et al., 2018). The emphasis on personal interests is low, while the emphasis on general interests is the highest. If not, the organization will fail particularly the educational institutions. The interests of organizational goals should not be harmed by the interests of individuals or communities. To make the organization work well, Henri Fayol suggests that personal interests should be subordinate to the interests of the organization (ethics) (Khan et al., 2018). The main focus is on the goals of the academic institutions, not the individual. This extends to all levels of the entire institutions, including organizational heads.

\section{Remuneration}

Salary refers to the income accumulated by an employee to do work or being employed by a company or organization (Calvin, 2017). However, compensation applies to a combination of compensation, options, incentives and other financial incentives. Moreover, salary provides a fundamental attraction for employees to carry out their work effectively (Yuliarini et al., 2017). At the same time, salary contributes to employee motivation. Wages are an important source of income for workers and determine their standard of living (Silva et al., 2019). Thus, 
salary affects the efficiency and output of organizational employees to accomplish the management goals, especially in the educational institutions since teachers in Bangladesh are not paid adequately.

\section{The Degree of Centralization}

Centralization is the degree to which formal authority is concentrated at the level of a region or organization. In a highly centralized system, top managers make most of the major organizational decisions, while lower-level employees have very little feedback (Darvishmotevali, 2019). Since only a few people are present, they can discuss the details of each decision in one meeting, so the decision-making process gets more effective. Organizational management and decision-making power must be fully balanced. It depends on the size and scale of the organization, including its hierarchy (Flessa et al., 2018). Moreover, centralization involves the centralization of decision-making authority among senior management (executive board). Besides, Henri Fayol said that decentralization is the exchange of lower-level decision-making bodies (middle-level and lower-level management) (Shaked \& Schechter, 2017). Therefore, a centralized organization plays the significant role to focus vision, to reduce costs, quick implementation of decisions and to improve quality work in the educational organizations as well.

\section{Scalar Chain}

The scalar principle is the principle of organization, that is, authority and obligation should flow in an uninterrupted straight line from highest to lowest. The official authorization line from the highest level to the lowest level is called the scalar chain (Poperwi, 2018). According to the Henri Fayol, there should be a top-to-bottom authority and communication chain, which managers or academic heads and subordinates should follow. The scalar principle means that a company should have a specific concept of authority, and that authority flows through the chain of commands, connecting one at a time. This line is the most basic organizational structure (Abdulkader et al., 2020). Thus, scalar chain is necessary for every organization to achieve its goals and to succeed in any organizations particularly in the educational institutions.

\section{Order}

Order management involves methods of acquiring, monitoring and processing customer orders. The order management process starts from placing an order and ends when the customer receives the goods (Dachyar \& Zufri, 2016). However, organizational order or direction provides guidance to all employees by creating formal reporting relationships that control the workflow of the educational organization. The formal outline of the order of academic institutions makes it easier to introduce new roles to the organization and provide common ready-made development methods (Adil Namiq, 2018). According to this management theory, the workers of an organization must have the right tools to enable them to work effectively in the organization. In addition to the operating sequence (the responsibilities of the manager or educational institutional heads), the work environment must be safe, clean and tidy (Wajdi, 2017). Organizational order thus plays a major role in 
influencing workers in the organization and in achieving its objectives.

\section{Equity}

The equity management theory also exists in the core principles of the organization. However, justice ensures that everyone has access to fair care, resources and development (Le Ber et al., 2018). The goal of fairness is to identify and remove barriers that hinder full participation in the organization's work. Moreover, fairness promotes cognitive diversity in decision-making and improves job satisfaction and employee engagement (Inuwa, 2017a). According to Henri Fayol, workers must be treated fairly. Employees must be in the right position in the institution to do the right thing (Inuwa, 2017b). Therefore, managers especially the academic heads should supervise and control this process and treat workers equally and fairly.

\section{Stability of Tenure of Personnel}

The theory of employee stability is for an organization to operate effectively, personnel (especially managers) must not join and leave the organization regularly (Steffens et al., 2016). There should have stability in employee and manager's retention. However, this management theory is the deployment and management of resources and should be consistent with the services provided by the organization (Pendola \& Fuller, 2018). The purpose of management is to reduce the turnover rate of workers and find the right employees in the right place. Key areas need to be handled properly, such as regular job changes and appropriate growth (Mitonga-Monga et al., 2017). Thus, Staff tenure stability reduces employee's turnover and increases productivity in the organization. Due to inefficient educational management, teachers and non-teaching stuffs of academic institutions in Bangladesh often switch their jobs. Thus, academic heads should focus on employee retention policy for sustainable and production education management.

\section{Initiative}

Initiative refers to starting, beginning or instructing in the organization. As employees provide different suggestions, the theory allows management to learn further ways to implement the predetermined plan (Wihler et al., 2017). However, this theory allows managers or organizational heads to learn more about the form of implementing predetermined strategies when workers make different suggestions (Dalcher \& Cooke-Davies, 2019). Henri Fayol also believes that workers should be allowed to share new ideas with managers. This inspires participation and involvement and creates added value for all organizations (especially educational institutions). Besides, employee planning is the source of organizational strength (Ionescu et al., 2018), and Henri Fayol has emphasized on taking initiative for growth and sustainability. Proper initiatives, therefore, enable teachers and other staffs of educational institutes to be involved and to be active in organizational practices to achieve their goals and objectives.

\section{Esprit de Corps}

Esprit de corps is a French phrase that refers to the organizational spirit as a concept in administrative management theory developed by Henri Fayol (Naz et al., 2019). Spirit de 
corps is a team cohesion within the organization and employees. The principle of esprit de corps of management theory represents the participation and unity of employees (Affandi et al., 2019). The organizational heads are responsible for the spiritual growth of the workplace in the personal and communication fields. The spirit of the employees contributes to the development of the educational organization and creates an environment of mutual trust and understanding in the academic institutions (Adeleye, 2017).

\section{Discussion and Conclusion}

This study has identified the managerial inefficiency in running the educational institutes in Bangladesh. The head of the institute is also having management skill gaps. Thus, it is referring Henri Fayol's 14 principals to apply for administrative management at academic institutions. The main aim of this study is to examine the management concerns facing Bangladesh's institutional heads in the field of education management. It also considers the core factors, obstacles and barriers of organizational leaders in the sectors of education management. Based on the existing literature and available information, this study is also suggesting the best solution to those challenges that are the strong barriers. It is also suggesting the academic heads to practice all the fourteen management principles for managerial efficiency. It is recommended that using Fayol's principles can improve and strengthen the management skills of institutional heads that will have a positive impact on achieving organizational goals and focusing on excellence in education. Furthermore, this research can draw the attention of organizational leaders who face various obstacles and difficulties in carrying out their managerial events in the field of educational management. It is found that head of academic institutes have enormous gaps and deficiencies in carrying out their respective performances and responsibilities in the educational institution concerning administrative skills, such as organization, monitoring, regulation, evaluation, encouragement and coordination. Hence, the outcomes of this study will play a crucial role in improving and enhancing the management skills of academic leaders in education management in Bangladesh. Besides, this study also strongly recommends that the management skills of institutional heads be strengthened and established by following the main components of the management principles developed by Henri Fayol that is mentioned in this paper. This review paper will also play a positive role in improving management skills and achieving organizational objectives, especially in Bangladesh and, to a large extent, elsewhere in the world.

\section{References}

Adam, A. (2019a). The Influence of Authority, Initiative, and Unity of Direction in Achieving Good Governance in Africa using M plus v8 Scientific Tool. Public Policy \& Administration Research, 9(4), 36-53. https://doi.org/10.7176/PPAR

Adam, A. (2019b). The Influence of Authority, Initiative, and Unity of Direction in Achieving Good Governance in Africa using Mplus v8 Scientific Tool The Influence of Authority , Initiative, and Unity of Direction in Achieving Good Governance in Africa using M plus v8. Public Policy and Administration Research, 9(4), 1-19. https://doi.org/10.7176/PPAR 
Adeleye, E. O. (2017). Impact of Leadership Behaviour on Job Satisfaction in Nigerian Public and Private Universities. The International Journal of Business \& Management, 3(10), $520-530$.

Adil Namiq, F. (2018). Most effective management style for modern workplace. International Journal of Engineering and Management Sciences, 3(3), 402-411. https://doi.org/10.21791/ijems.2018.3.33

Affandi, L. A., Purwana, D., \& Hanafi, M. F. (2019, August). Evolution of Leadership in Esprit de Corps: Evidence from Military Organization. In First International Conference on Administration Science (ICAS 2019) (pp. 399-403). Atlantis Press.

Al-Hammadi, A. (2019). An Investigation into the Effectiveness of the Higher Colleges of Technology Quality Programme in the United Arab Emirates Submitted by Abdulrahman Al-Hammadi , B . Sc ., M . Sc . For the Degree of Doctor of Philosophy University of Glamorgan January 2010. ProQuest (January), 1-361.

Amin, A. (2018). The UN Sustainable Development Goals and Teacher Development for Effective English Teaching in Bangladesh: A Gap that Needs Bridging. Journal of Teacher Education for Sustainability, 20(2), 118-138. https://doi.org/10.2478/jtes-2018-0019

Bacud, S. A. D. (2020). HENRI FAYOL'S PRINCIPLES OF MANAGEMENT AND ITS EFFECT TO ORGANIZATIONAL LEADERSHIP AND GOVERNANCE. Journal of Critical Reviews, 7(11), 162-167. https://doi.org/10.31838/jcr.07.11.25

Bank, C. M. Van Der, \& Popoola, B. A. (2018). A Theoretical Framework of Total Quality Assurance in a University of Technology A Theoretical Framework of Total Quality Assurance in a University of Technology. Academic Journal of Interdisciplinary Studies, 3(4), 401. https://doi.org/10.5901/ajis.2014.v3n4p401

Bell, R. L., \& Bodie, N. D. (2019). Delegation, Authority and Responsibility : Removing the Rhetorical Obstructions in the Way of an Old Paradigm Delegation, Authority and Responsibility: Removing the Rhetorical Obstructions in the Way of an Old Paradigm. Research Gate, (April), 1-16.

Calvin, O. Y. (2017). The Impact of Remuneration on Employees' Performance : A Study of Abdul Gusau Polytechnic, Talata-Mafara and State College of Education Maru, Zamfara State. Nigerian Chapter of Arabian Journal of Business and Management Review, 4(2), 34-43. https://doi.org/10.12816/0037554

Castillo, F. A., \& Hallinger, P. (2017). Systematic review of research on educational leadership and management in Latin America. Educational Management Administration \& Leadership, 46(2), 207-225. https://doi.org/10.1177/1741143217745882

Christens, B. D., Byrd, K., Peterson, N. A., \& Lardier, D. T. (2018). Critical Hopefulness Among Urban High School Students. Journal of Youth and Adolescence, 0(6), 1-14. https://doi.org/10.1007/s10964-018-0889-3

Cletus, H. E., \& Ibrahim, A. D. (2018). Prospects and Challenges of Workplace Diversity in 
Modern Day Organizations: A Critical Review. SCIENDO, 9(2), 35-52. https://doi.org/10.2478/hjbpa-2018-0011

Connolly, M., James, C., \& Fertig, M. (2017). The difference between educational management and educational leadership and the importance of educational responsibility. Research Gate, (January 2018), 1-17. https://doi.org/10.1177/1741143217745880

Cooper, L., \& Hughes, H. (2017). First-year international graduate students' transition to using a United States university library. IFLA journal,43(4), 361-378. https://doi.org/10.1177/0340035217723355

Dachyar, M., \& Zufri, L. (2016). Improving order management system in pump industry. ARPN Journal of Engineering and Applied Sciences, 11(7), 4917-4923.

Dalcher, D., \& Cooke-Davies, T. (2019). Managing Strategic Initiatives. Managing Projects in a World of People, Strategy and Change, VI(Vii), 105-113. https://doi.org/10.4324/9780429449741-12

Darvishmotevali, M. (2019). Decentralization and Innovative Behavior: The Moderating Role of Supervisor Support. International Journal of Organizational Leadership, 8(1), 31-45. https://doi.org/10.33844/ijol.2019.60204

Flessa, J., Bramwell, D., Fernandez, M., \& Weinstein, J. (2018). School leadership in Latin America 2000-2016. Educational Management Administration and Leadership, 46(2), 182-206. https://doi.org/10.1177/1741143217717277

Fortunato, J. A., Gigliotti, R. A., \& Ruben, B. D. (2017). Racial Incidents at the University of Missouri: The Value of Leadership Communication and Stakeholder Relationships. International Journal of Business Communication, 54(2)(10), 199-209. https://doi.org/10.1177/2329488416687056

Hallinger, P. (2017). Surfacing a hidden literature: A systematic review of research on educational leadership and management in Africa. Educational Management Administration \& Leadership, O(7), 1-23. https://doi.org/10.1177/1741143217694895

Inuwa, M. (2017a). Relationship between Job Equity and Performance of Employee: A Literature Review. International Journal of Business and Management Future, 1(1), 8-15. https://doi.org/10.46281/ijbmf.v1i1.110

Inuwa, M. (2017b). Role of Job Equity on Employee Performance. International Journal of Management Science Research, 3(1), 168. https://doi.org/10.46281/ijbmf.v1i1.110

Ionescu, G. H., Firoiu, D., Pîrvu, R., Bădîrcea, R., \& Drăgan, C. (2018). Implementation of integrated management systems and corporate social responsibility initiatives-A Romanian Hospitality industry perspective. Sustainability (Switzerland), 10(10), 1-15. https://doi.org/10.3390/su10103684

Khan, A. K., Moss, S., Quratulain, S., \& Hameed, I. (2018). When and How Subordinate Performance Leads to Abusive Supervision: A Social Dominance Perspective. Journal of 
Management, 44(7), 2801-2826. https://doi.org/10.1177/0149206316653930

Khasawneh, A. L., \& Hammadat, M. (2015). The impact of the delegation of authority on employees ' performance at great Irbid municipality: case study. Pakistan Development Review, (January 2020), 1-23. https://doi.org/10.5296/ijhrs.v5i3.8062

Kim, T. Y., Wang, J., \& Chen, J. (2018). Mutual Trust Between Leader and Subordinate and Employee Outcomes. Journal of Business Ethics, 149(4), 945-958. https://doi.org/10.1007/s10551-016-3093-y

Le Ber, M. J., Monzani, L., \& Yang, Y. (2018). Equity, Diversity, and Inclusion in Organizations: What Impact does Leader Identity Have? Academy of Management Proceedings, 1(1), 15305. https://doi.org/10.5465/ambpp.2018.15305symposium

Masud, M. H., Akram, W., Ahmed, A., Ananno, A. A., \& Mourshed, M. (2021). Towards the effective E-waste management in Bangladesh: a review. Environmental Science and Pollution Research, 1(7), 1250-1276. https://doi.org/10.1007/s11356-018-3626-2

Mitonga-Monga, J., Flotman, A., \& Cilliers, F. V. N. (2017). Organisational citizenship behaviour among railway employees in a developing country: effects of age, education and tenure. Southern African Business Review, 21(10), 385-406. http://www.dhsprogram.com

Naz, T., Malik, A. B., \& Din, M. (2019). A Voyage of Esprit-De-Corps: A Sectorial Comparison. Global Social Sciences Review, IV(II), 10-19. https://doi.org/10.31703/gssr.2019(iv-ii).02

Pendola, A., \& Fuller, E. (2018). Principal Stability and the Rural Divide. Journal of Research in Rural Education, 34(1), 1-20. https://doi.org/10.18113/p8jrre3401

Poperwi, L. (2018). Principles of Management: Their Relevance and Applicability in the Management of Current and Future Organisations. Scholars Journal of Economics,Business and Management (SJEBM), 5(9), 808-812. https://doi.org/10.21276/sjebm.2018.5.9.1

Rahman, M. M. (2020). Cloud Computing in Bangladeshi Higher Educational Institutions : Influential Office of Cloud Computing in Bangladeshi Higher Educational Institutions: Influential Factors and Adoption Model. Research Gate, (February), 1-14.

Rozario, S. L. (2018). Higher Education in Bangladesh : An Inquiry into Educational Equity at Notre Dame University Bangladesh (NDUB) A Dissertation Presented by Subal Lawrence Rozario Submitted to the Graduate School of Education Lesley University in partial fulfillment of t. ProQuest, (May), 1-298.

Ruben, B. D., \& Gigliotti, R. A. (2016). Communication: Sine Qua Non of Organizational Leadership Theory and Practice. International Journal of Business Communication, O(11), 1-19. https://doi.org/10.1177/2329488416675447

Abdulkadir, S., Adeagbo, D. O., Mohammed, S., \& Nuruddeen, U. (2020). An Interpretive Structural Modelling of Henry Fayol's Management Principles in Construction Project of Nigeria. Journal of Construction and Building Materials Engineering, 6(3), 5-13. 
https://doi.org/10.46610/jocbme.2020.v06i03.002

Sanyang, L. (2019). Work Force Diversity and Its Impact on Organisational Performance. Research Gate, 20(January), 1-14. https://doi.org/10.33102/abqari.vol20no2.212

Serdyukov, P. (2017). Innovation in education: what works, what doesn ' $t$, and what to do about it? Journal of Research in Innovative Teaching \& Learning, 10(1), 4-33. https://doi.org/10.1108/JRIT-10-2016-0007

Service, C. (2019). Discipline Management Strategies and Compliance Success in the Rivers State Open Access Discipline Management Strategies and Compliance Success in the Rivers State Civil Service Dr Patrick N Nwinyokpugi, 2 Robbinson, Ruebenba Ebbi. Research Gate, O(March), 1-14.

Shaked, H., \& Schechter, C. (2017). Systems thinking among school middle leaders. Educational Management Administration and Leadership, 45(4), 699-718. https://doi.org/10.1177/1741143215617949

Shimin, T. I. (2018). Measuring Service Gap of Higher Education in Bangladesh - A Comparative Study between Public University and Private University. International Journal of Science and Business, 2(3), 491-502. https://doi.org/10.5281/ZENODO.1345070

Silva, C., Faria, P., \& Vale, Z. (2019). Multi-period observation clustering for tariff definition in a weekly basis remuneration of demand response. Research Gate, 12(7), 1-8. https://doi.org/10.3390/en12071248

Steffens, N. K., Shemla, M., Wegge, J., \& Diestel, S. (2016). Organizational Tenure and Employee Performance: A Multilevel Analysis. Group and Organization Management, 39(6), 664-690. https://doi.org/10.1177/1059601114553512

Taylor, M., La Jolla, C., \& June. (2020). No TitleA Mixed-Method Study Exploring: The Emergence of Leadership Skills in Special Education Administrators. SELL Journal, 5(1), 55.

Uzuegbu, C. (2016). Henry Fayol' s 14 Principles of Management: Implications for Libraries and Information Centres. Journal of Information Science Theory and Practice, 3(2). 10.1633/JISTaP.2015.3.2.5

Valente, S., Monteiro, A. P., Valente, S., \& Monteiro, A. P. (2019). The relationship between teachers 'emotional intelligence and classroom discipline management The relationship between teachers ' emotional intelligence and classroom discipline management. Psychology in the Schools, 56(5). https://doi.org/10.1002/pits.22218

Wajdi, B. N. (2017). The Differences Between Management And Leadership. Sinergi : Jurnal Ilmiah Ilmu Manajemen, 7(1), 75-84. https://doi.org/10.25139/sng.v7i1.31

Wihler, A., Blickle, G., Ellen, B. P., Hochwarter, W. A., \& Ferris, G. R. (2017). Personal Initiative and Job Performance Evaluations: Role of Political Skill in Opportunity Recognition and Capitalization. Journal of Management, 43(5), 1388-1420. https://doi.org/10.1177/0149206314552451 


\section{Macrothink}

International Journal of Human Resource Studies

ISSN 2162-3058 2021, Vol. 11, No. 3

Yaya, S., Bishwajit, G., \& Ekholuenetale, M. (2017). Factors associated with the utilization of institutional delivery services in Bangladesh. PloS one, 12(2), 0171573. https://doi.org/10.1371/journal.pone.0171573

Yuliarini, S., Bt Ku Ismail, K. N. I., \& Bararoh, T. (2017). Concept of Remuneration and Management Behavior Evaluation in Indonesia. Asian Journal of Accounting Research, 2(1), 1-6. https://doi.org/10.1108/ajar-2017-02-01-b001

\section{Copyright Disclaimer}

Copyright for this article is retained by the author(s), with first publication rights granted to the journal.

This is an open-access article distributed under the terms and conditions of the Creative Commons Attribution license (http://creativecommons.org/licenses/by/4.0/). 